\title{
ANATOMICAL BASIS FOR THE INTRAHEPATIC GLISSONIAN APPROACH DURING HEPATECTOMIES
}

\author{
Bases anatômicas para o acesso intra-hepático aos pedículos glissonianos durante hepatectomias
}

Rodrigo Cañada Trofo SURJAN, Fábio Ferrari MAKDISSI, Marcel Autran Cesar MACHADO

From the Department of Surgery, University of São Paulo, São Paulo, SP, Brazil.

HEADINGS - Liver. Anatomy. Techniques. Glissonian. Hepatectomy.
ABSTRACT - Background: Anatomical liver resections are based on some basic technical principles such as vascular control, ischemic area delineation to be resected and maximum parenchymal preservation. These aspects are achieved by the intrahepatic glissonian approach, which consists in accessing the pedicles of hepatic segments within the hepatic parenchyma. Small incisions on well-defined anatomical landmarks are performed to approach the pedicles, making dissection of the hilar plate unnecessary. Aim: Analyze parameters in liver anatomy related to intrahepatic surgical technique to glissonians pedicles, to set the normal anatomy related to the procedure and thereby facilitate the attainment of this technique. Methods: Anatomical parameters related to the intrahepatic glissonian approach were studied in 37 cadavers. Measurements were performed with precision instruments. Data were expressed as mean \pm standard deviation. The subjects were divided into groups according to gender and liver weight and groups were compared statistically. Results: Twenty-five cadavers were male and 12 female. No statistically significant difference was observed in virtually all parameters when groups were compared. This demonstrates the consistency of the anatomical parameters related to the intrahepatic glissonian approach. Conclusion: The results obtained in this study made possible major technical advances in the realization of open and laparoscopic hepatectomies with intrahepatic glissonian approach, and can help surgeons to perform liver resections by this method.

\section{Correspondence: \\ Rodrigo Cañada Trofo Surjan \\ E-mail: medrod2003@yahoo.com.br \\ Financial source: none \\ Conflicts of interest: none}

Received for publication: 01/12/2014 Accepted for publication: 24/02/2015

DESCRTTORES - Fígado. Anatomia. Técnicas. Glissoniano. Hepatectomia
RESUMO - Racional: Ressecções hepáticas anatômicas são baseadas em alguns princípios técnicos básicos, como o controle vascular, delimitação de área isquêmica a ser ressecada e máxima preservação do parênquima. Isto pode ser obtido pelo acesso intra-hepático aos pedículos glissonianos, que consiste em controle dos pedículos dos segmentos dentro do parênquima hepático. Pequenas incisões ao redor da placa hilar, em marcos anatômicos bem definidos, são utilizadas para acesso aos pedículos, tornando desnecessária a dissecção do hilo hepático. Objetivo: Analisar parâmetros da anatomia do fígado relacionada com a técnica cirúrgica da abordagem intra-hepática aos pedículos glissonianos, para definir a anatomia normal relacionada ao procedimento e, assim, facilitar a realização desta técnica. Métodos: Parâmetros anatômicos relacionados à abordagem intra-hepática aos pedículos glissonianos foram estudados em 37 cadáveres. As medições foram realizadas com instrumentos de precisão. Os dados foram expressos em média \pm desvio-padrão. Os indivíduos foram divididos em grupos de acordo com o sexo e peso do fígado e os grupos foram comparados estatisticamente. Resultados: Vinte e cinco cadáveres eram do sexo masculino e 12 do feminino. Não houve diferença estatisticamente significativa em praticamente todos os parâmetros quando os grupos foram comparados. Isto demonstra a consistência dos parâmetros anatômicos relacionadas com a técnica intra-hepática de acesso glissoniano. Conclusão: Os resultados obtidos neste estudo possibilitaram grandes avanços técnicos na realização de hepatectomias abertas e laparoscópicas com abordagem intra-hepática aos pedículos glissonianos, e pode ajudar cirurgiões a realizar procedimentos seguros e eficazes por este método.

$\mathrm{T}$ he precise knowledge of the anatomy of the liver is the most important factor in the practice of liver surgery. Presently, hepatic surgery is a segment-oriented surgery based on knowledge of the intra-hepatic disposition of glissonian pedicles ${ }^{1}$.

The biggest challenges while performing a hepatectomy consist of the prevention and control of bleeding, preserving as much healthy parenchyma as possible, and achieving good oncological results. Anatomical hepatectomies are those in which the resected hepatic parenchyma corresponds to the segmental division of the liver.

In 1989, Galperin and Karagiulian ${ }^{2}$ described a technique in which dissection associated with digital exposure within the hilar plate made the exposure of the glissonian pedicles easy and fast with low bleeding. One year later, Takasaki et al..$^{22}$ described a similar technique. Launois and Jamieson standardized the technique $e^{6,7}$. Finally, Machado et al. ${ }^{8,9}$ described an innovative technique based on the studies of Galperin ${ }^{2}$ and Launois ${ }^{6}$, the intrahepatic glissonian approach, that precludes any dissections of the hilar plate. With small incisions on the liver capsule over welldefined anatomical landmarks it allows the approach of the pedicles of both right 
and left liver ${ }^{8,9}$. Lately, these same anatomical landmarks were used to laparoscopic procedures ${ }^{11,13}$.

One of the main issues that could be source of criticism to this technique is the possibility of anatomical variations and variability between gender, weight, height and hepatic volume. These could affect definitively the success and safety of the technique. Since the intra-hepatic glissonian approach does not comprise direct dissection and exposure of glissonian pedicles, precise anatomical knowledge of the intrahepatic disposition of these structures is necessary to perform it effectively and safely.

The aim of this study was to analyze parameters of the liver anatomy related to the surgical technique of the intrahepatic approach to glissonian pedicles to define the normal anatomy related to the procedure and thus facilitate the technique.

\section{METHODS}

Thirty-seven livers from adult cadavers were studied at the University of São Paulo, School of Medicine, São Paulo, SP, Brazil. All cases in which some local factor, such as previous surgical manipulation and cirrhosis, could alter the original anatomy of the upper abdomen of the corpse were excluded from this study. The dissection was carried out with proper surgical instruments for cadaveric dissection, and the measurements were performed with precise measuring instruments like a digital $200 \mathrm{~mm}$ caliper with a resolution of $0.01 \mathrm{~mm}$ (Mitutoyo 500-197 @-20B). Glissonian pedicles from left and right liver were encircled using specific anatomical landmarks previously published ${ }^{8,9,11,13}$ (Figures 1 and 2).

Nomenclature of hepatic anatomy and terminology of hepatic segments were used as defined by the Brisbane Convention held in $2000^{20}$. The results are expressed as the median (mean \pm standard deviation).

Cadavers were than divided in groups by gender and liver weight (more than $1300 \mathrm{~g}$ and $1300 \mathrm{~g}$ or less). The

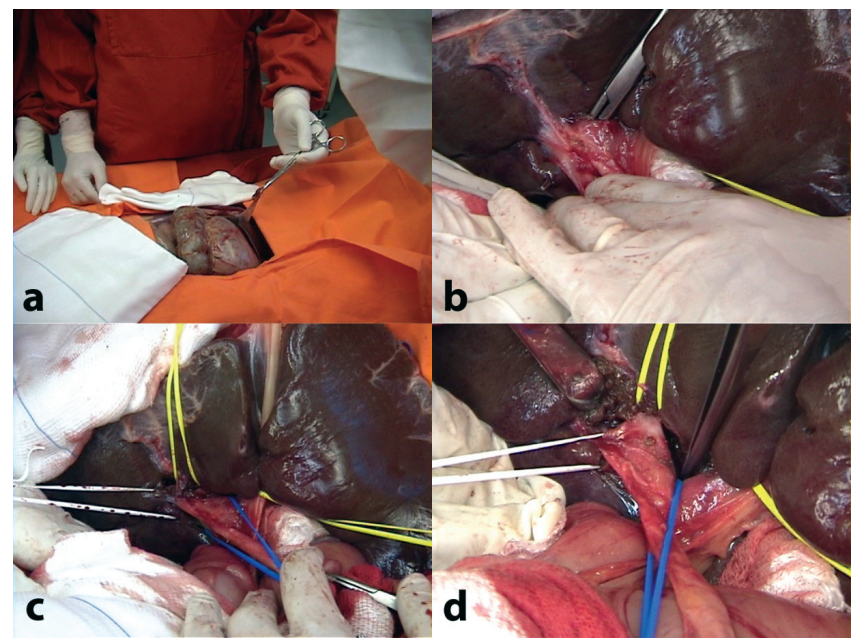

FIGURE 1 - Cadaveric dissection and retrieval of right-sided glissonian pedicles: a) anatomical parameters were studied with the liver in situ, preserving the findings and parameters encountered during an actual surgery; b) intrahepatic approach for right pedicle, using published technique ${ }^{9,11}$; c) final view after retrieval of right-sided glissonian pedicles: blue tape is encircling the right main pedicle (containing portal triad from segments 5 to 8 ); yellow tape (superior) is encircling the right anterior pedicle (segments 5 and 8); white tape is encircling the right posterior pedicle (segments 6 and 7); d) after removal of liver tissue, intrahepatic pedicles are exposed. statistical test applied to tables was the chi-square. Continuous variables with normal distribution were compared by the unpaired Student t test.

\section{RESULTS}

Twenty-five cadavers were males and twelve females. The median weight of the liver was $1320 \mathrm{~g}$, ranging between $780 \mathrm{~g}$ and $1800 \mathrm{~g}(1325.6 \pm 256.4 \mathrm{~g})$. In 26 cases, the incisura dextra of Gans was present, there was no incisura in one and in 10 livers it was covered by hepatic parenchyma. In 21 cases, it contained the pedicle of segment 6 , and in five cases, it contained the pedicles of the segments 6 and 7. In 15 cases, the bridge between segments 3 and 4 was not present, whereas it was subtle in four cases and it was present in 18 cases, uniting the cited segments around the umbilical fissure and ligament.

The length of the Arantius ligament had a median value of $35 \mathrm{~mm}(34.5 \pm 7.14 \mathrm{~mm})$. The left hepatic vein presented a common trunk with the middle hepatic vein in 19 cases, while in the remaining 18 cases, these veins had separate paths between the liver and the inferior suprahepatic vena cava. Among 18 cases in which the left hepatic vein drained independently into the vena cava, in nine cases, there was an identifiable isolated path that could be encircled outside the liver parenchyma. In the remaining nine cases, this path was not identifiable.

\section{Left pedicle}

The left pedicle gives rise to the pedicles of segment 4 (with branches into segments $4 \mathrm{a}$ and $4 \mathrm{~b}$ ) and the pedicle to the left lateral sector, which contains the branches for segments 2 and 3 . The trunk of the left pedicle shortly after his origin of the right-left bifurcation had a median diameter of $28 \mathrm{~mm}$ $(28.2 \pm 6.4 \mathrm{~mm})$. This diameter varied between 18 and $45 \mathrm{~mm}$.

The pedicle of segment 4 had a median diameter of 28 $\mathrm{mm}$ and range between 11 and $49 \mathrm{~mm}(26.8 \pm 8.2 \mathrm{~mm})$. The distance between its origin and the main portal bifurcation had a median of $22 \mathrm{~mm}(21 \pm 5.3 \mathrm{~mm})$ while ranging between $7 \mathrm{~mm}$

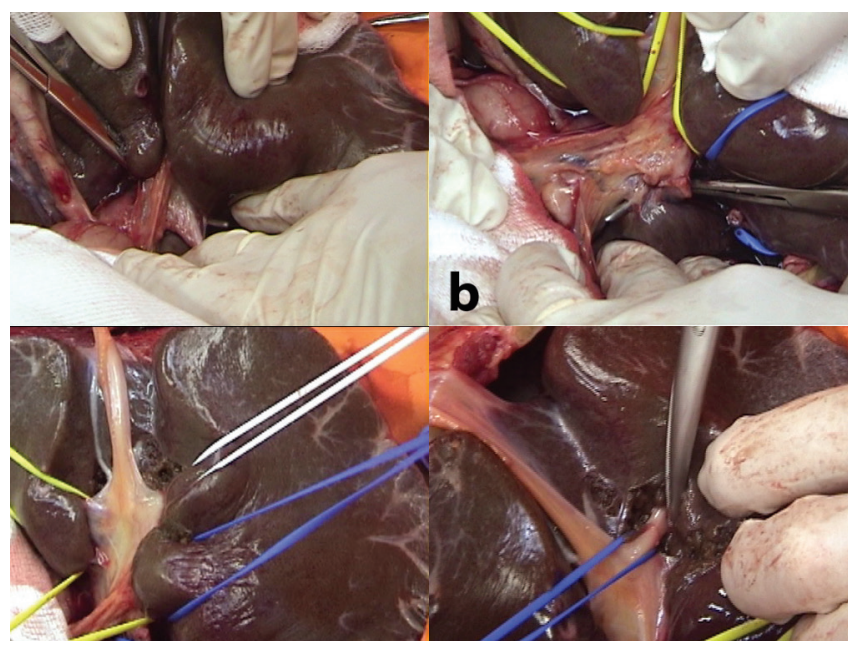

FIGURE 2 - Cadaveric dissection and retrieval of leftsided glissonian pedicles: a) intrahepatic approach for left pedicle, using published technique ${ }^{8,13}$; b) intrahepatic approach for pedicle from segment 1 ; c) final view after retrieval of left-sided glissonian pedicles: blue tape (inferior) is encircling the segment 1 pedicle (containing portal triad from segment 1 ); yellow (inferior) tape is encircling left main pedicle (segments 2 to 4 ); white tape is encircling the segment 3 pedicle; yellow (superior) tape is encircling segment 4 pedicle; blue tape (superior) is encircling the segment 2 pedicle; d) after removal of liver tissue, intrahepatic pedicles are exposed. 
and $30 \mathrm{~mm}$. The median diameter of the pedicle of segment 4 a was $11 \mathrm{~mm}$, ranging from 5 to $18 \mathrm{~mm}(11.4 \pm 3 \mathrm{~mm})$. The pedicle of segment $4 \mathrm{~b}$ had a median diameter of $10 \mathrm{~mm}$ and it varied between 4 and $20 \mathrm{~mm}(10.5 \pm 3.2 \mathrm{~mm})$.

The pedicle of the left lateral section (segments 2 and 3 ) showed a median diameter of $38 \mathrm{~mm}(35.9 \pm 7.1 \mathrm{~mm})$, ranging between 21 and $48 \mathrm{~mm}$. The distance between its origin near the hilar plate and its bifurcation between segments 2 and 3 ranged from 1 to $5 \mathrm{~mm}$, with a median of $3 \mathrm{~mm}(2.6 \pm 0.8 \mathrm{~mm})$. The pedicle of segment 2 had a median diameter of $18 \mathrm{~mm}$ $(19.5 \pm 5.4 \mathrm{~mm})$, ranging between 10 and $35 \mathrm{~mm}$. The pedicle of segment 3 ranged between 10 and $32 \mathrm{~mm}$ with a median of $17 \mathrm{~mm}(17.7 \pm 5.3 \mathrm{~mm})$.

When cadavers were divided in groups by gender, there was no statically significant difference in the pedicles from the left liver (Table 1). When livers with $1300 \mathrm{~g}$ or less where compared to those with more than $1300 \mathrm{~g}$, only the segment 4 pedicle presented statically significant difference (Table 2 ).

TABLE 1 - Left liver pedicles: groups divided by gender

\begin{tabular}{|l|c|c|c|}
\hline & Female $(\mathrm{n}=12$ & Male $(\mathrm{n}=25)$ & $\mathrm{p}$ \\
\hline Left pedicle $(\mathrm{mm})$ & $27,3 \pm 5,4$ & $28,6 \pm 6,9$ & NS \\
\hline Pedicle Sg 2,3 (mm) & $36,4 \pm 7,7$ & $35,6 \pm 7,0$ & NS \\
\hline Pedicle Sg 2 (mm) & $19,2 \pm 6,8$ & $19,6 \pm 4,9$ & NS \\
\hline Pedicle Sg 3 (mm) & $19,6 \pm 5,4$ & $16,8 \pm 5,2$ & NS \\
\hline Pedicle Sg 4 (mm) & $24,9 \pm 10,6$ & $27,7 \pm 6,8$ & NS \\
\hline Pedicle Sg 4a (mm) & $11,9 \pm 1,6$ & $11,2 \pm 3,5$ & NS \\
\hline Pedicle Sg 4b (mm) & $10,1 \pm 3,3$ & $10,7 \pm 3,2$ & NS \\
\hline Pedicle Sg 1 (mm) & $10,3 \pm 1,7$ & $11,3 \pm 3,8$ & NS \\
\hline
\end{tabular}

$\mathrm{Sg}=$ segment

TABLE 2 - Left liver pedicles: groups divided by liver weight

\begin{tabular}{|l|c|c|c|} 
& $\leq 1300 \mathrm{~g}(\mathrm{n}=15)$ & $>1300 \mathrm{~g}(\mathrm{n}=22)$ & $p$ \\
\hline Left pedicle $(\mathrm{mm})$ & $28,7 \pm 6,5$ & $27,8 \pm 6,5$ & NS \\
\hline Pedicle Sg 2,3 (mm) & $36,1 \pm 6,9$ & $35,7 \pm 7,4$ & NS \\
\hline Pedicle Sg 2 (mm) & $19,1 \pm 5,4$ & $19,7 \pm 5,6$ & NS \\
\hline Pedicle Sg 3(mm) & $18,1 \pm 5,8$ & $17,4 \pm 5,1$ & NS \\
\hline Pedicle Sg 4 (mm) & $26,9 \pm 8,6$ & $26,7 \pm 8,1$ & NS \\
\hline Pedicle Sg 4a (mm) & $12,0 \pm 2,3$ & $11,0 \pm 3,4$ & NS \\
\hline Pedicle Sg 4b (mm) & $12,0 \pm 3,7$ & $9,5 \pm 2,4$ & $<0,01$ \\
\hline Pedicle Sg 1(mm) & $10,6 \pm 3,2$ & $11,3 \pm 3,4$ & NS \\
\hline
\end{tabular}

$\mathrm{Sg}=$ segment

\section{Right pedicle}

The right pedicle had a median diameter of $26 \mathrm{~mm}(26.8 \pm 4.7$ $\mathrm{mm})$, ranging between 18 and $37 \mathrm{~mm}$. The distance from its origin soon after the main portal bifurcation to its bifurcation into the anterior and posterior right pedicles ranged between 12 and $41 \mathrm{~mm}$ with a median distance of $27 \mathrm{~mm}(26.2 \pm 6.8 \mathrm{~mm})$. The pedicle of the right anterior section (comprising segmental pedicles of segments 5 and 8) had a median diameter of $16 \mathrm{~mm}$, ranging from 10 to $31 \mathrm{~mm}(17.1 \mathrm{~mm} \pm 4.9 \mathrm{~mm})$. The pedicle of the right posterior section (containing segmental pedicles of segments 6 and 7) also varied between 10 and $31 \mathrm{~mm}$ with a median of $18 \mathrm{~mm}(18.4 \pm 5.6 \mathrm{~mm})$.

When cadavers were divided in groups by gender, there was no statically significant difference in the pedicles from the right liver (Table 3). When livers with $1300 \mathrm{~g}$ or less were compared, there was only statically significant difference in the pedicle of segments 6 and 7 (Table 4).

TABLE 3 - Right liver pedicles: groups divided by gender

\begin{tabular}{|l|c|c|c|}
\hline & Female $(n=12)$ & Male $(n=25)$ & $p$ \\
\hline Rt ped. - Rt bif. $(\mathrm{mm})$ & $26,5 \pm 7,6$ & $26,0 \pm 6,5$ & NS \\
\hline Right pedicle $(\mathrm{mm})$ & $27,0 \pm 4,6$ & $26,7 \pm 4,9$ & NS \\
\hline Pedicle Sg 5,8 $(\mathrm{mm})$ & $16,5 \pm 6,2$ & $17,4 \pm 4,3$ & NS \\
\hline Pedicle Sg 6,7 (mm) & $19,5 \pm 6,4$ & $17,9 \pm 5,2$ & NS \\
\hline
\end{tabular}

$\mathrm{Rt}=$ righ; ped=pedicle; bif=bifurcation; $\mathrm{Sg}=$ segment
TABLE 4 - Right liver pedicles: groups divided by liver weight

\begin{tabular}{|l|c|c|c|} 
& $\leq 1300 \mathrm{~g}(\mathrm{n}=15)$ & $>1300 \mathrm{~g}(\mathrm{n}=22)$ & $\mathrm{p}$ \\
\hline Rt ped. - Rt bif. $(\mathrm{mm})$ & $26,5 \pm 5,2$ & $26,0 \pm 7,8$ & NS \\
\hline Right pedicle (mm) & $26,9 \pm 5,2$ & $26,7 \pm 4,5$ & NS \\
\hline Pedicle Sg 5,8 (mm) & $17,3 \pm 5,6$ & $17,0 \pm 4,6$ & NS \\
\hline Pedicle Sg 6,7 (mm) & $20,7 \pm 6,0$ & $16,8 \pm 4,8$ & $<0,05$ \\
\hline
\end{tabular}

$\mathrm{Rt}=$ righ; ped=pedicle; bif=bifurcation; $\mathrm{Sg}=$ segment

Hilar plate and relationship with glissonian pedicles

The average distance between the hilar plate and the portal bifurcation into right and left branches was $3.5 \mathrm{~mm}$ (SD:1.0 $\mathrm{mm})$, ranging from 1 to $7 \mathrm{~mm}$. This bifurcation occurred at a median angle of $35^{\circ}$, ranging between $25^{\circ}$ and $45^{\circ}\left(35.1 \pm 5.2^{\circ}\right)$. For the distance between the bifurcation of the main portal pedicle and the distal insertion of the Arantius ligament (the closest point between the ligament and the left portal vein referred to as the distal Arantius ligament), the median value was $33 \mathrm{~mm}$, ranging between 20 and $40 \mathrm{~mm}(32.9 \pm 42.2 \mathrm{~mm})$. The distance between the bifurcation of the main pedicle into the right and left pedicles and the base of the round ligament (the point where it comes in contact with the liver parenchyma) varied between $20 \mathrm{~mm}$ and $45 \mathrm{~mm}$, with a median of $33 \mathrm{~mm}$ $(32.6 \pm 6.2 \mathrm{~mm})$. There was no statistically significant difference between groups when parameters related to the hilar plate were studied.

\section{DISCUSSION}

The knowledge of the intrahepatic arrangement of glissonian pedicles gains importance from the fact that the elements of the portal triad, upon entering the parenchyma, are still surrounded by an extension of the liver capsule and runs together within the liver. This fact was already known in 1640, according to descriptions of the Dutch Leiden Johannes Walaeus dated two years before the description of Francis Glisson about the capsule covering the liver on all its faces, except for the diaphragmatic face (bare area) ${ }^{21}$. This feature allows for the simultaneous and simple control of vascular inflow (arterial and portal branches) and biliary drainage for all liver segments described by Couinaud ${ }^{1}$.

The technique of the intrahepatic approach to the glissonian pedicles is based on the surgical approach of hepatic segments through access to elements of the hepatic pedicle contained by a capsule of connective tissue that encompasses them in a single beam. Opening and extensive dissection of the hepatic parenchyma become unnecessary, since the parts of the liver with the corresponding pedicle of the segments to be resected are accessed only through small incisions on the hepatic capsule on previously determined landmarks $s^{8,9,11,13}$. The description of these specific landmarks was a direct result of the data collected in this study, as well as the completion of cadaver dissections performed for this purpose.

Another advancement of liver surgery was yet to come: the realization of anatomical hepatectomies by videolaparoscopy. Intrahepatic access to glissonian pedicles fit perfectly with laparoscopy, since it avoids unnecessary extensive dissection along the hepatic hilum during laparoscopic procedures, which are technically complex and potentially time-consuming with high morbidity. Moreover, the basic principles and benefits of open surgery were maintained, such as maximum preservation of the parenchyma, independent approach of all segments and sections of the liver, enabling surgeries in two stages, sequential surgery in cases of recurrence of the underlying disease, and preserving the safety and low mortality achieved with open surgery $10,11,12,13,14,15$.

As demonstrated, all of these advances are inseparable from the developments in the knowledge of hepatic anatomy. This knowledge, the development of techniques, and surgical 
training were achieved through cadaveric dissection and precise anatomical measurements. This is the first time that accurate measures related to the intrahepatic approach to glissonian pedicles during anatomical hepatectomies were performed. In this study, in contrast to studies, all anatomical parameters were studied with the liver in situ, preserving the findings and parameters encountered during an actual surgery (except for the weighing of the organ) $)^{1,3,4,5,19}$. Thus, parameters of normal or usual anatomy were determined. These data are useful to those who intend to perform such procedures, both in the preparation before the onset of clinical practice and during possible technical difficulties while performing a hepatectomy. Simple parameters such as the thickness of a pedicle or the angle between two pedicles, the thickness of a vein, or knowledge of what might be inside a hepatic fissure, can be used to avoid accidents during a procedure or make it easier to perform.

The results of this study have enabled major technical and scientific advances related to the intrahepatic approach to glissonian pedicles, either by open surgery or by laparoscopy. During the study period, the anatomical knowledge obtained by cadaveric dissections was immediately applied to actual anatomical hepatectomies, publications and workshops, where these parameters could be taught effectively with great reproducibility ${ }^{16,17,18,23}$.

\section{CONCLUSION}

The data obtained in this paper, as well as the absence of statically significant difference in almost all parameters related to the intrahepatic glissonian approach confirm the steadiness of the anatomy of intrahepatic structures. These findings strongly corroborate to the fact that this technique is safe and highly reproducible.

\section{REFERENCES}

1. Couinaud C. Surgical Anatomy of the Liver Revisited. Paris: Paris; 1989.

2. Galperin EI, Karagiulian SR. A new simplified method of selective exposure of hepatic pedicles for controlled hepatectomies. HPB Surg. 1989;1:19-30.

3. Glisson F. Anatomia hepatis. London: Dugard; 1654.

4. Healey Jr JE, Schroy PC. Anatomy of the biliary ducts within the human liver; Analysis of the prevailing pattern of branchings and the majorvariations of the biliary ducts. Arch Surg. 1953;66:599-616.
5. Hjortsjo $\mathrm{CH}$. The topography of the intrahepatic duct systems. Acta Anat. 1951;11:599-615.

6. Launois B, Jamieson GG. The posterior intrahepatic approach for hepatectomy or removal of segments of the liver. Surg Gynecol Obstet. 1992;174:55-58.

7. Launois B. Hepatectomy: the posterior intrahepatic approach. $\mathrm{Br} J$ Surg. 1997;84:291-292.

8. Machado MA, Herman P, Machado MC. Anatomical resection of left liver segments. Arch Surg. 2004;139(12):1346-9.

9. Machado MA, Herman P, Machado MC. Standardized technique for segmental right liver resections. Arch Surg. 2003;138(8):918-20.

10. Machado MA, Kalil AN. Glissonian approach for laparoscopic mesohepatectomy. Surg Endosc. 2011 Jun;25(6):2020-2.

11. Machado MA, Makdissi FF, Galvão FH, Machado MC. Intrahepatic Glissonian approach for laparoscopic rightsegmental liver resections. Am J Surg. 2008 Oct;196(4):e38-42.

12. Machado MA, Makdissi FF, Herman P, Surjan RC. Intrahepatic Glissonian approach for pure laparoscopic left hemihepatectomy. J Laparoendosc Adv Surg Tech A. 2010 Mar;20(2):141-2.

13. Machado MA, Makdissi FF, Surjan RC, Herman P, Teixeira AR, C Machado MC. Laparoscopic resection of left liver segments using the intrahepatic Glissonian approach.Surg Endosc. 2009 Nov;23(11):26159.

14. Machado MA, Makdissi FF, Surjan RC, Kappaz GT, Yamaguchi N. Two-stage laparoscopic liver resection for bilateral colorectal liver metastasis. Surg Endosc. 2010 Aug;24(8):2044-7.

15. Machado MA, Makdissi FF, Surjan RC, Oliveira AC, Pilla VF, Teixeira AR. Intrahepatic Glissonianapproachforlaparoscopic righttrisectionectomy. J Laparoendosc Adv Surg Tech A. 2009 Dec;19(6):777-8;

16. Machado MA, Makdissi FF, Surjan RC. Laparoscopic liver resection: personal experiencewith107 cases. RevCol Bras Cir.2012Dec;39(6):4838. English, Portuguese

17. Machado MA, Surjan RC, Makdissi FF. Intrahepatic glissonian approach for single-port laparoscopic liver resection. J Laparoendosc Adv Surg Tech A. 2014 Aug;24(8):534-7.

18. Machado MA, Surjan RC, Makdissi FF.Intrahepatic Glissonian approach for pure laparoscopic right hemihepatectomy. Surg Endosc. 2011 Dec;25(12):3930-3.

19. McIndoe AH, Counseller VS. The bilaterality of the liver. Arch Surg. 1927;15:589-612.

20. Strasberg SM. Nomenclature of hepatic anatomy and resections: a review of the Brisbane 2000 system. J Hepatobiliary Pancreat Surg. 2005;12:351-5.

21. Sutherland F, Harris J. Claude Couinaud: a passion for the liver. Arch Surg. 2002;137(11):1305-10.

22. Takasaki K, Kobayashi S, Tanaka S, Saito A, Yamamoto M, Hanyu F. Highly anatomically systematized hepatic resection with Glissonean sheath code transection at the hepatic hilus. Int Surg. 1990;75(2):73-77.

23. Topal B, Aerts R, Penninckx F. Laparoscopic intrahepatic Glissonian approach for right hepatectomy is safe, simple and reproducible. Surg Endosc. 2007;21:2011. 